of a section of stellar physics. The magnetic observatory, which was started towards the end of 1949 , is now in full operation and is equipped with a set of Watson magnetographs, a set of La Cour magnetographs and the usual accessories; the equipment of the magnetic observatory will shortly be further strengthened by the addition of an Askania magnetic field balance, as well as a set of $Q H M$ and $B M Z$ instruments. The principal instrument of the ionospheric observatory, which started functioning from the beginning of 1952, is an automatic multifrequency ionosphere recorder of the latest type designed by the U.S. Bureau of Standards. The magnetic and ionospheric section naturally has an electronics laboratory attached to it. Recently an equipment for the study of solar radio radiation in the $100 \mathrm{Mc} . / \mathrm{s}$. region has been built in the electronics laboratory and has been brought into regular use. Mr. B. N. Bhargava, who had his specialized training in radiophysics in the United States, is in charge of the magnetic and ionospheric section. The stellar physics section has made a modest beginning with a 20-in. Cassegrain reflector by Grubb as its principal instrument. Though old, it is an excellent and very versatile telescope which originally belonged to the now disused Observatory of Poona called after His Highness Maharajah Takhtasinghji of Bhavnagar. This telescope was presented to the Kodaikanal Observatory many years ago, but had remained unused and dismantled. Recently it has been installed for regular use after reconstructing several of its missing or damaged parts, and has been named the Bhavnagar telescope. Work on planetary spectra and some aspects of stellar spectroscopy is being begun with this instrument. Our plans for the development of the stellar physics section include the acquisition of a large Schmidt-Cassegrain telescope and a large reflector of about 100-in. aperture as soon as the necessary funds become available.

The developments that have already taken place have necessitated considerable improvements in our workshop facilities. The Observatory machine shop is now equipped for meeting most requirements of a modern astrophysical observatory; an optical workshop for the Observatory is also one of our projects.

\section{PASTURE AND FODDER DEVELOPMENT IN MEDITERRANEAN COUNTRIES}

$\mathrm{T}$ HERE are a number of countries in the south of Europe and the north of Africa which have sufficient in common to be grouped as the Mediterranean area but in which there is also diversity of topography and, to some extent, of climate: the rainfall varies from 200 to $1,000 \mathrm{~mm}$. a year. The prevalence of limestone rock with soils derived therefrom is a characteristic of this area; but there are considerable areas of igneous rocks, although here, too, practically all the overlying soils are directly related to these rocks. The olive and the evergreen oak are characteristics of the area; indeed, it may be said that a map of the olive and evergreen oak is a map of the typical Mediterranean area. The past history of these countries-invasions, wars and tribal movements-have necessarily affected the people's way of life and the agricultural traditions that have come to be established, but the influence of the past is not now easy to diagnose in its entirety.

There are some specialized crops, particularly the vine and the olive, that are long established and the management of which is generally good; but the cultivation of the more utilitarian crops is mostly unsatisfactory, and arable work on a rotational basis is very weak. Wheat is a dominant crop, and an alternation of wheat and fallow is the chief rotation.

Except in some parts of the south of France, there is a very great deal of pressure on the land to secure the livelihood of the people, and this arises to a considerable extent from the deterioration that has put some areas completely out of cultivation. There has in the past been a good deal of forest destruction, not only to make room for arable cultivation but also to provide wood for buildings and for ships; in consequence, there has been considerable denudation and erosion, and over-grazing has intensified this decline.

The keeping of small animals, particularly sheep and goats, is very common. The keeping of one or two animals by a family is quite normal, but there are also professional shepherds with their flocks. None of the stock, however, is developed for one primary purpose ; almost every animal is a multiplepurpose animal to produce whatever labour, milk, meat, skin and so forth it can.

In addition to the defects in crop husbandry itself is the lack of integration between crop and animal husbandry. There is very little pasture specifically cultivated for grazing. Grazing is largely a random affair, and the stock graze in areas that are inaccessible for ploughing or on crop residues. The shepherds who keep flocks of sheep have little grazing ground which is their own, and these shepherds make financial arrangements wherever they can for their flocks to graze.

The Mediterranean farmer has for a long time followed tradition without receiving much inspiration for the development of new ideas, but it does seem that these people are amenable to help and guidance in raising the level of their farming. The pasture and forage problems are crucial to the progress that can be made, and in this connexion the Organization for European Economic Development has produced a report, entitled "Pasture and Fodder Development in Mediterranean Countries"*, which should be the means of big developments and considerable transformation. For some time now the Food and Agricultural Committee of the Organization has been concerned with the development of grassland in Europe, and, following a conference in Paris during May 1950, it published "Farm Advisory Methods for Grassland Improvement". It was during the Paris conference that the need for studying pasture and fodder production in the Mediterranean area was stressed and, in preparation for a conference on the matter, the countries concerned were surveyed by a number of experts from the United States, Australia, South Africa and Great Britain. Each of these experts worked with suitable colleagues in the country concerned, and reports on the various countries are published in Part 2 of the present publication of the Organization for European Economic Development. The reports were discussed first with representatives of the various countries and

* Pasture and Fodder Development in Mediterranean Countries. (Technical Assistance Mission No. 56.) Pp. 176. (Paris: Organization Office, 1951.) n.p. 
then at a conference in Rome in June 1951, when a number of important recommendations were agreed.

A fundamental consideration in pasture and forage development is necessarily the climate and its effect on the growing season. Information about climatic conditions is essential if experience in one area is to be helpful in another, and if the introduction of plants from one region to another is to be carried out rationally. It was therefore recommended in the report that studies of climate and the keeping of reliable meteorological records must be undertaken, and suggestions for the minimum necessary undertakings are made.

A few of the indigenous plants in these countries have been developed commercially ; but for the most part they have not been systematically studied and assessed, although this is work that provides essential data for pasture improvement and, as the report points out, can be effective in a very short time. The conference also urged that each country should, in due course, introduce and test species and strains from other countries, and that a systematic programme of seed production should be made possible.

Following systematic study in a country of plants involved in pastures, the integration of pastures and fodder for grazing with its whole scheme of arable farming must be studied and developed. It is suggested that a first step in this matter might be the incorporation of an annual fodder crop into the familiar cereal/fallow rotation, and that, where the climate permits, the fallow be replaced by an appropriate legume, so that in due course this might be developed into a wheat/legume/legume rotation, with wheat every third year, or, in the drier parts, the rotation might be wheat/legume/fallow. The lengthening of rotations in this way should, where it is possible, bring in grazing animals. This will admittedly be difficult in some areas of small holdings where there is no communal grazing, but it is a programme to be aimed at. Moreover, at the present time animal production is very much affected by seasonal food production, and an appropriate development of the continuous production of fodder all the year round is a vital matter.

There are many other lines of work suggested for the improvement of pasture and forage; but the conference has not been unmindful of important economic aspects. Improvements in production will be justified only when and where there are appropriate markets, and in some cases potential markets will need development. The need for increasing the consumption of milk in these countries is one important matter in this connexion. Better farm implements are required; and it is realized, too, that there must be a development in the use of fertilizers (at present much of the land is very poor, particularly in phosphate and nitrogen), and a definite price policy in the development of fertilizers will be required. The need for credit facilities also received the attention of the conference.

The conference expressed the hope that the interest of pasture and fodder developments in the Mediterranean countries will justify the establishment of research stations and pilot farms, and also of a journal and a Mediterranean grassland committee.

A number of technical papers bearing on the subject of the conference were read at the Rome meeting and are produced in Part 3 of the report.

N. M. CoMrer

\section{NEWS and VIEWS}

\section{Directorship of the Lister Institute :}

\section{Sir Alan Drury, C.B.E., F.R.S.}

THE retirement is announced of Sir Alan Drury from the directorship of the Lister Institute, London, which he has held since 1943. Sir Alan assumed the directorship at a difficult period in the history of the Institute, the work of which had been much disorganized by the War. He brought to his task not only his outstanding personal qualities of patience and quiet efficiency, but also a wide knowledge of many aspects of medical research which he had acquired through long service on the scientific staff of the Medical Research Council. His experience included clinical research with the late Sir Thomas Lewis, many years of distinguished work in experimental pathology at Cambridge and a period of most valuable service during the War in the Council's headquarters office. Under Sir Alan's guidance, the Lister Institute has been restored to its position as a centre of active medical research, sustaining its earlier reputation for work in immunochemistry and becoming well known for investigations of blood groups and blood products; it has also taken on new and important responsibilities in connexion with the preparation of sera and vaccines. During his directorship Sir Alan has served as a member of the Medical and the Agricultural Research Council, and both bodies owe much to his help and advice. It is inevitable that the many administrative burdens which Sir Alan has had to shoulder should have greatly restricted his opportunities for personal research at the Lister Institute. It is good, therefore, to know that after his retirement such opportunities will be restored to him when he takes up his work in the Agricultural Research Council's Institute of Animal Physiology. Sir Alan's personal qualities and scientific attainments ensure that the research in experimental pathology which is to be under his care in this Institute will develop on sound lines.

Dr. A. A. Miles

Dr. A. A. Miles, who is to succeed Sir Alan Drury as director of the Lister Institute, has been, since 1946, director of the Division of Biological Standards at the National Institute for Medical Research ; for the past five years he has also been deputy director of the Institute. Before his appointment to the scientific staff of the Medical Research Council, Dr. Miles had become recognized as one of the leading bacteriologists in Great Britain. He had had fruitful periods of work at the London School of Hygiene, at Cambridge, at the Postgraduate Medical School in London, and as professor of bacteriology at University College Hospital Medical School, London, where he showed himself to be an outstandingly successful teacher. During his tenure of the latter appointment he had, throughout the War, the responsible position of sector pathologist within the Emergency Medical Service. As director of the Division of Biological Standards at the National Institute for Medical Research, Dr. Miles has had the task of continuing 